\title{
Sosialisasi Pengembangan Wisata Desa Berbasis Digital Marketing Di Desa Mataram Pringsewu
}

\author{
Fery Hendi Jaya ${ }^{1}$, Muh Thohirin ${ }^{1}$, Yunita Mauliana ${ }^{1}$, Sari Utama Dewi ${ }^{1}$ \\ , Diana Nur Afni ${ }^{1}$ \\ Universitas Sang Bumi Ruwa Jurai \\ feryhendi_jaya@yahoo.co.id, muhtohirin21@gmail.com, \\ yunita.mauliana@gamail.com,saridewi.dewi1981@gmail.com
}

\begin{abstract}
Abstrak
Berdasarkan hasil pengamatan dan koordinasi Pendahuluan yang dilaksanakan bersama Kepala Desa Mataram, diperoleh beberapa catatan potensi wilayah sebagai. Potensi bangunan bendung yang menjadi tanggung jawab PU kab dan masih belum beroprasi, Potensi wisata gupit dan Potesi ternak sapi. Dengan potensi-potensi yang ada, maka dapat dikembangkan menjadi lebih bermanfaat sehingga dapat meningkatkan Pendapatan dan kesejahteraan masyarakat di wilayah Pekon Mataram. Dalam rangka meningkatkan potensi wisata Pekon Mataram, perlu melihat dan mempelajari beberapa hasil penelitian terkait pemanfaatan potensinya. Metode pelaksanaan menggunakan metode survei. Dari beberapa lokasi yang sudah disurvei memiliki potensi beraneka macam permasalahan dan solusinya. Potensi yang menjadi tema kami adalah sosialisai iklan telaga gupit berbasis digital marketing menggunakan facebook. Setelah dilaksanakan pengabdian kepada masyarakat dapat disimpulkan bawha Wisata gupit dapat diketahui oleh masyarakat luar desa melalui iklan difacebook mencapai 4.957 akun.
\end{abstract}

Kata Kunci : Digital Marketing, Wisata Desa, Sosialisasi

\begin{abstract}
Based on the results of preliminary observations and coordination carried out with the Village Head of Mataram, several records of the potential of the region were obtained. The potential of the weir building which is the responsibility of the district $P U$ and is still not operating, the potential for gupit tourism and the potential for cattle. With the existing potentials, it can be developed to be more useful so that it can increase the income and welfare of the people in the Mataram Pekon area. In order to increase the tourism potential of Pekon Mataram, it is necessary to see and study several research results related to the utilization of its potential. The implementation method uses a survey method. From several locations that have been surveyed, there are various potential problems and solutions. The potential that became our theme is the socialization of Gupit Lake advertisements based on digital marketing using Facebook. After carrying out community service, it can be concluded that Gupit Tourism can be known by people outside the village through Facebook advertisements reaching 4,957 accounts.
\end{abstract}

Keywords: Digital Marketing, sosialitaion, village desination 


\section{PENDAHULUAN}

Berdasarkan hasil pengamatan dan koordinasi Pendahuluan yang dilaksanakan bersama Kepala Desa Mataram, diperoleh beberapa catatan potensi wilayah sebagai berikut: 1) Potensi bangunan bendung yang menjadi tanggung jawab PU kab dan masih belum beroprasi. 2) Potensi wisata gupit. 3) Potesi ternak sapi. Dengan potensi-potensi yang ada, maka dapat dikembangkan menjadi lebih bermanfaat sehingga dapat meningkatkan Pendapatan dan kesejahteraan masyarakat di wilayah Pekon Mataram.

Dalam rangka meningkatkan potensi wisata Pekon Mataram, perlu melihat dan mempelajari beberapa hasil penelitian terkait pemanfaatan potensi sebagai berikut:

Berdasarkan kaian yang dilakukan oleh Nur Hayatin, Dini Kurniawati dan Evi D. Wahyuni, Tahun 2017 dengan judul "Pembangunan Dan Pelatihan Pengelolaan Website Untuk Mendukung Promosi Kampung Wirausaha (E-Lun) Kelurahan Sisir Kota Batu", dapat diketahui bahwa dengan pengelolaan website, maka daerah tersebut dapat mempromosikan obyeknya lebih luas (Novalia dkk, 2021).

Dalam kajian yang dilaksanakan oleh Arthana K.R., dkk Tahun 2020,Penerapan Website Untuk Optimalisasi Pemasaran Online Wisata Desa Selat. Mengatakan untuk meningkatkan kunjungan wisatawan ke objek wisata, sangat perlu disediakan promosi online mengingat masyarakat pencinta wisata lebih banyak mencari referensi terlebih dahulu di internet sebelum menuju lokasi wisata. Dapat diketahui bahwa di Pekon Mataram memiliki potensi wisata telaga gupit yang belum memiliki website (Arthna dkk, 2020). Didesa mataram memiliki potensi wisata yang dapat di manfaat oleh warga sebagai lapangan kerja baru.

\section{METODE PELAKSANAAN}

Kegiatan ini pada dasarnya merupakan kegiatan dalam bentuk pengabdian kepada masyarakat. Metode pelaksanaan menggunakan metode survei, langkah-langkanya sebagai berikut : 1) Persiapan, 2) Perencanaan, 3) Sosialisasi, 4) Pendampingan, dan 5) Monioring dan Evaluasi.

\section{Persiapan}

Persiapan yang dilakukan adalah berkoordinasi dengan pihak mitra PKM kemudian dilanjutkan dengan mensurvei lokasi. lokasi yang disurvei ternak sapi milik warga dusun podosari. Ternak sapi didusun podomoro dikelola secara tradisional baik sistem pakanyan maupun sistem pengelolaan kotoranya. Setalah itu mensurvei lokasi pompa hidram yang ada di bantaran sungai sekampung, yang sudah lama dibangun namun tidak dapat beroprasi. Survey terakhir adalah survey pada telaga gupit. Dari beberapa lokasi yang sudah disurvei memiliki potensi beraneka macam permasalahan dan solusinya. Potensi yang menjadi tema kami adalah sosialisai iklan telaga gupit berbasis digital marketing menggunakan facebook. Hal yang perlu disiapkan adalah suratsurat adminitrasi dari desa, leptop, proyektor dll. 


\section{Perencanaan}

Kegiatan pengabdian kepada masyarakat dilakukan pada hari selasa 2 November 2021. Dengan peserta masyarakat desa matara. Pada sosialisasi kegiatan ini masyarakat diundang resmi dari kepala desa. Sosialisasi dilakukan didalam gedung balai desa menggunakan peralatan utama computer, proyektor dan pengeras suara.

\section{Sosialisasi}

Sosialisasi kegiatan pengabdian pada masyarakat dengan metode ceramah dan praktik langsung.

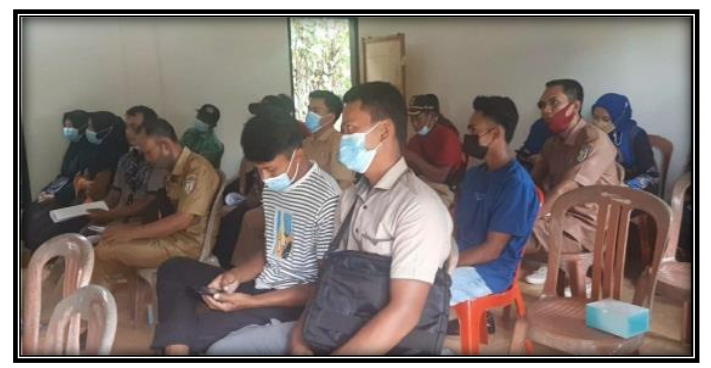

Gambar 1. sosialisasi digital marketing.

\section{Pendampingan}

Pendampingan pada masyarakat dalam kegiatan pengabdian kepada masyarakat ini bertujuan supaya materi yang telah diberikan benar-benar dapat diterima dan diterapkan oleh masyarakat.

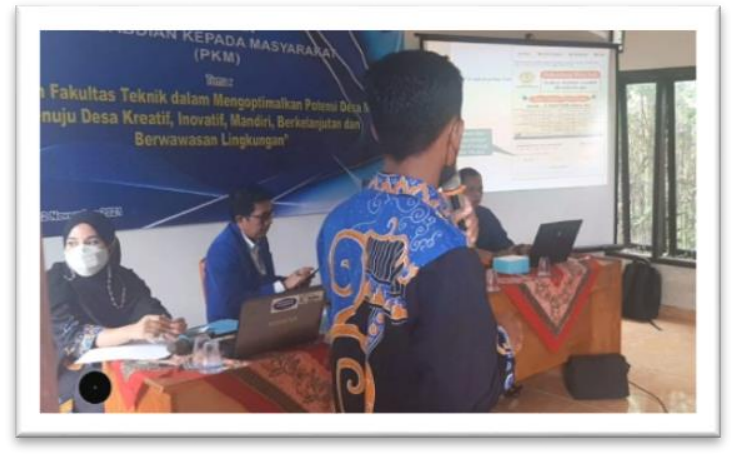

Gambar 2. Pendampingan Pada Masyarakat

\section{Monitoring dan Evaluasi}

Monitoring pada kegiatan pengabdian kepada masyarakat dilakukan dengan cara melihat konten yang telah iklan pada facebook.

\section{HASIL DAN PEMBAHASAN}

Hasil dalam pelaksanaan kegiatan pengabdian kepada masyarakat ini dapat dirangkum sebagai berikut :

1. Terjalinnya kerjasama antara masyarakat, penelola wisata desa gupit dan aparat desa terutama peningkatan sumber daya manusia secara manajerial dan teknis pada wisata desa gupit desa mataram kec. Gadingrejo kab. Pringsewu. 
2. Terbentuknya wadah dan organisasi pengelola wisata desa gupit dari beberapa unsur masyarakat, dalam menghadapi pengembangan wisata berupa penggunaan teknologi informasi dan jaringan (internet)

3. Hasil suatu tayangan iklan selama 4 hari dengan bayaran Rp. 66.000 melalui facebook mendapatakn jumlah pengunjung sebanyak 1.488 akun.

\section{KESIMPULAN}

Setelah dilaksanakan pengabdian kepada masyarakat dapat disimpulkan bawha Wisata gupit dapat diketahui oleh masyarakat luar desa dan jumlah pengunjunng akun facebook meningkat

\section{Saran}

Adapaun saran yang bisa kami berikan setelah kegiatan pengabdian kepada masyarakat, Sebaiknya dibuatkan applikasi berbasis android untuk wisata-wisata desa yang ada di desa mataram.

\section{UCAPAN TERIMA KASIH}

Penulis mengucapkan terima kasih kepada bapak Rahmat Riyadi selaku kepala desa di desa materam yang telah mengijinkan dan memberikan fasilitas kepada kami. Terima kasih juga kepada Dr. Lina Maulidiana, S.H., M.H. Selaku Rektor Universitas Sang Bumi Ruwa Jurai yang telah menduku penuh kegiatan pengabdian kepada masyarakat. Novalia, S.Pd,. M.Si. selaku ketua LPPM memberi dukungan moral dan dana terhadap program pengabdian kepada masyarakat ini. Untuk tim pengabdian kepada masyarakat Muh Thohirin, S.T., M.T. dan Yunita Mauliana, S.T., M.T. saya ucapkan terimakasih atas kerjasama tim yang baik sehingga Pengabdian kepada Masyarakat dapat berjalan dengan baik.

\section{DAFTAR PUSTAKA}

Novalia., Astuti. H. W., Apriyanto. S., Sasoro. F., 2021, Buku Pedoman pengabdian Kepada Masyarakat universitas Sang Bumi Ruwa Jurai, Saburai Pres, Bandar Lampung.

Arthana. I. K. R., Tirtayani. L. A., Astawan. I. G., Adnyani4. K. E. K., 2020, Penerapan Website Untuk Optimalisasi Pemasaran Online Wisata Desa Selat, Proceeding Senadimas Undiksha, Bali.

Hayatin. N., Kurniawati. D., Wahyuni. E., 2017, Pembangunan Dan Pelatihan Pengelolaan Website Untuk Mendukung Promosi Kampung Wirausaha (E-Lun) Kelurahan Sisir Kota Batu, Jurnal Dedikasi, Jawa Barat. 